\title{
PERBEDAAN PENGARUH PEMULIHAN AKTIF (JOGGING) DAN PEMULIHAN PASIF (DUDUK) TERHADAP PENURUNAN KADAR ASAM LAKTAT
}

\author{
Oleh \\ Fajar Apollo Sinaga ${ }^{1}$, Ngolu Nasip Martua Sihombing ${ }^{1}$ \\ ${ }^{I}$ Fakultas Ilmu Keolahragaan, Universitas Negeri Medan \\ Email: sinaga_fajar@yahoo.com
}

\begin{abstract}
Abstrak
Penelitian ini bertujuan untuk mengetahui apakah ada pengaruh pemulihan aktif dan pemulihan pasif serta pemulihan manakah labih baik terhadap penurunan kadar asam laktat darah setelah melakukan sprint 100 meter. Penelitian ini dilakukan di Stadion Universitas Negeri Medan pada April 2017, dengan metode eksperimen. Sampel penelitian berjumlah 10 orang Mahasiswa IKOR angkatan 2014 UNIMED. Hasil Penelitian kadar asam laktat pada saat pre tes pada kelompok pemulihan aktif (jogging) diperoleh rata-rata sebesar $13,96 \mathrm{mmol} / \mathrm{L}$ dan setelah pemulihan aktif dengan jogging selama 10 menit (post tes) terdapat penurunan kadar asam laktat menjadi 10,68 mmol/L. Sedangkan pada kelompok pasif diperoleh kadar asam laktat rata-rata $13,56 \mathrm{mmol} / \mathrm{L}$ dan setelah pemulihan pasif (duduk) selama 10 menit terjadi penurunan kadar asam laktat sebesar 12,8 mmol/L. Hasil uji antara data pre-test dan post test kadar asam laktat pada kelompok pemulihan aktif diperoleh nilai significancy $0,001(\mathrm{p}<0,05)$ yang berarti ada perbedaan yang signifikan kadar asam laktat antara pre-test dan post-test. Sedangkan pada kelompok pemulihan pasif diperoleh nilai significancy 0,063 $(p>0,05)$ yang berarti tidak ada perbedaan yang signifikan kadar asam laktat antara pre-test dan post-test. Hasil uji statistik diperoleh nilai $\mathrm{p}=\mathbf{0 , 0 2 5}$. Karena nilai $p<0,05$ berarti dapat diambil kesimpulan bahwa terdapat perbedaan yang signifikan antara penurunan kadar asam laktat pada lari sprint 100 meter yang diberi pemulihan aktif (jogging) dengan pemulihan pasif (duduk). Dari hasil data tersebut dapat ditarik kesimpulan berarti terdapat perbedaan yang signifikan pemulihan aktif dengan pemulihan pasif terhadap penurunan kadar asam laktat pada lari sprint 100 meter mahasiswa IKOR 2014 UNIMED.
\end{abstract}

Kata Kunci: Kadar Asam Laktat, Pemulihan Aktif, Pemulihan Pasif

\section{A. PENDAHULUAN}

Pada dasarnya setiap orang yang melakukan pekerjaan ataupun berolahraga dengan maksimal atau intensitas tinggi akan mengalami kelelahan. Kelelahan adalah menurunnya kualitas dan kuantitas kerja atau olahraga yang disebabkan (akibat dari) melakukan kerja atau olahraga tertentu (Griwiyono, 2012).

Sprint merupakan salah satu cabang olahraga atletik dan pelarinya disebut dengan sprinter, lari sprint terbagi dalam lari jarak 100 meter, 200 meter dan 400 meter (Irwansyah, 2006). Dalam cabang olahraga ini kecepatan merupakan komponen fisik 
yang esensial dan merupakan salah satu faktor pendukung keberhasilan seorang atlet.

Kecepatan adalah kemampuan untuk melakukan gerakan-gerakan yang sejenis secara berturut-turut dalam waktu yang sesingkat-singkatnya, atau kemampuan untuk menempuh suatu jarak dalam waktu yang sesingkat-singkatnya (Harsono, 1998). Dalam lari sprint, kecepatan larinya ditentukan oleh gerakan berturut-turut lari kaki yang dilakukan secara cepat.

Lari sprint memerlukan kecepatan yang membuat daya tahan tubuh cepat berkurang, karena kebutuhan oksigen tidak terpenuhi seluruhnya oleh tubuh, sehingga terjadi penumpukan asam laktat. Oleh karena itu sistem energi yang digunakan adalah sistem glikolisis anaerobik dan ATP-PC. Ciri-ciri dari sistem glikolisis anaerobik adalah (1) Menyebabkan terbentuknya asam laktat yang dapat menyebabkan kelelahan, (2) Tidak membutuhkan Oksigen, (3) Hanya menggunk-an sumber energi karbohidrat (glikogen dan glukosa), dan (4) Energi yang dilepaskan hanya cukup untuk resintesis ATP dalam jumlah yang sedikit (Guntara, 2014). Sistem ATP-PC atau sistem fosfagen merupakan sumber energi utama untuk aktifitas yang berintensitas sangat tinggi, seperti lari 100 sprint meter. Aktifitas fisik yang dilakukan dengan intensitas tinggi dapat menyebabkan peningkatan kadar asam laktat dalam darah maupun otot (Fox, 1993).

Asam Laktat merupakan produk akhir dari salah satu jalur energi dalam tubuh yang dikenal sebagai glikolisis. Kadar asam laktat yang tinggi ini menyatakan ketidak mampuan sistem pemasokan energi aerobik. Suplai energi dari sumber anaerobik memancar ke dalam tindakan. Asam laktat yang tinggi menimbulkan asidosis pada dan disekitar sel otot, lingkungan asam ini dapat sangat mengganggu berbagai mekanisme sel otot. Sistem enzim aerobik pada sel otot dapat dianggap sebagai pabrik tempat terjadinya suplai energi aerobik. Sistem enzim ini disabotase oleh keadaan asidosis, yang mengakibatkan menurunnya kapasitas endurance aerobik. Keadaan ini dapat berlangsung berhari-hari sebelum sistem ini dapat pulih kembali dan kapasitas aerobik kembali ke tingkatan semula. Asidosis akan merusak dinding sel otot. Keadaan ini menyebabkan kebocoran dari sel otot ke dalam aliran darah, misalnya kenaikan kadar urea dan CPK merupakan tanda dari kebocoran dinding sel otot.

Laktat merupakan intermediate product dari metabolisme glukosa. Laktat merupakan sampah metabolisme anaerobik, proses ini berlangsung tanpa adanya oksigen. Kadar asam laktat dalam orang sehat dalam keadaan istirahat sekitar 1-2 M/L. 
Kadar laktat yang tinggi yang timbul akibat beban kerja yang berat dapat memberikan efek yang merugikan (Jansen, 2012).

Penimbunan asam laktat akan menimbulkan kelelahan dan menurunkan kinerja fisik. Kelelahan atau fatigue adalah kelelahan otot yang mengalami penurunan kemampuan kontraksi, karena suplai oksigen $\left(\mathrm{O}_{2}\right)$ dalam sel otot menurun. Penurunan kualitas dan kuantitas kerja atau olahraga ini disebabkan intensitas dan durasi kerja atau olahraga itu telah menyebabkan terjadinya gangguan homeostasis. Oleh karena itu kelelahan adalah citra subjektif dari adanya gangguan homeostasis, yang berdampak pada menurunnya kualitas dan kuantitas kerja atau penampilan seseorang dalam olahraga (kesehatan/prestasi).

Latihan-latihan dengan intensitas yang tinggi akan mengakibatkan meningkatnya kadar asam laktat yang tinggi dan dapat mengganggu kapasitas koordinasi. Kapasitas koordinasi sangat penting pada olahraga yang memerlukan keterampilan teknis yang tinggi seperti misalnya sepak bola, tenis dan karate. Latihan hendaknya tidak dilakukan pada kandungan asam laktat diatas 6-8 M/L, karena koordinasi akan terganggu sedemikian rupa sehingga latihan keterampilan ini tidak akan membawa efek positif apapun.

Peningkatan kadar asam laktat, dapat mempengaruhi kemampuan kerja maksimal serabut otot. Kandungan asam laktat yang tinggi juga dapat meningkatkan risiko cedera melalui asidosis di dalam otot, akan muncul lubang-lubang kecil pada jaringan otot, dan sistem fosfat keratin terganggu oleh kadar laktat yang tinggi, pada otot yang asam pembentukan kembali fosfat kreatinin tertunda. Oleh karena itu dianjurkan untuk menghindari kadar asam laktat yang tinggi selama latihan sprint. Untuk mengurangi kelelahan yang terjadi maka kadar asam laktat dalam darah maupun otot harus segera dibersihkan sampai pada batas ambang normal.

Kadar asam laktat akan mengalami penurunan apabila aktivitas fisik dihentikan dan pada saat pemulihan. Cara yang terpenting untuk mempercepat pembuangan asam laktat adalah meningkatkan aliran darah, meningkatkan cardiac output, meningkatkan transport laktat, sehingga cepat membentuk energi kembali. Proses pemulihan yang baik adalah apabila seseorang yang telah melakukan proses pemulihan tersebut tidak merasa lelah lagi akibat aktifitas fisik yang dilakukan sebelumnya dan siap melakukan aktifitas fisik selanjutnya. Masa pemulihan adalah suatu proses yang kompleks yang 
bertujuan untuk mengembalikan energi tubuh, memperbaiki jaringan otot yang rusak setelah berolahraga, dan memulai suatu proses adaptasi tubuh terhadap olahraga. Pemulihan kondisi fisik ada dua, yaitu pemulihan aktif dan pemulihan pasif. Pemulihan aktif adalah apabila setelah berolahraga, dilanjutkan dengan latihan pada kuantitas dan kualitas yang lebih ringan hingga kadar metabolit kembali kebatas normal (Bompa, 2009). Tehnik pemulihan aktif ini adalah adalah suatu metode pemulihan yang mengacu pada kecepatan menghilangkan kadar asam laktat. Aktivitas yang dilakukan secara umum berupa latihan aerobic ringan.

Intensitas latihan aerobic selama recovery aktif tidak lebih dari $60 \%$ dari denyut nadi maksimal. Aktivitas ringan akan menurunkan akumulasi asam laktad $62 \%$ dalam 10 menit pertama dan akan bertambah 26\% pada 10-20 menit berikutnya. Jogging adalah salah satu bentuk pemulihan aktif yang dilakukan untuk mengurangi kadar asam laktat. Selain untuk pemulihan aktif Jogging juga termasuk olahraga yang mempunyai manfaat besar bagi kesehatan tubuh dan bisa dilakukan oleh siapapun baik wanita dan pria disegala umur. Jogging adalah salah satu bentuk olahraga yang dilakukan dengan cara lari-lari kecil. Pada saat berjalan kaki menampakkan menyentuh tanah secara bergantian. Jogging bisa juga digunakan sebagai pemanasan atau pendidingan pada olahraga yang lain, seperti sepakbola, lari, dan olahraga lainnya.

Menurut Harsono (1988) pemulihan pasif adalah menghentikan segala aktivitas sesudah latihan seperti duduk atau tiduran dilapangan. Pemulihan pasif adalah cara fisiologis utama untuk memulihkan kapasitas kerja. Pemulihan pasif yaitu suatu pemulihan tanpa adanya aktifitas fisik, yaitu diam, istirahat total yaitu mengembalikan lagi kondisi fisik seseorang agar seperti semula, serta memperbaiki kerusakankerusakan kecil pada otot (Arief, 2011). Apabila sesudah latihan segera menghentikan segala aktivitas olahraga dan dengan melakukan metode pemulihan pasif penurunan akumulasi asam laktat hanya 50\%. Teori dasar yang mengatakan bahwa aktivitas sederhana membantu sirkulasi darah, dalam hal ini mempercepat perpindahan asam laktat dari otot ke hati untuk selanjutnya diubah menjadi glukosa melalui siklus cori. Pemulihan dikatakan pasif apabila aktivitas/olahraga dihentikan segera tanpa melalui tahap untuk mengurangi baik kualitas dan kuantitas olahraga. Tahap pemulihan yang dilakukan mempengaruhi kemampuan tubuh dalam mengeliminasi bahan meta-bolit, termasuk asam laktat. Selama tahap awal waktu pemulihan, sebagian besar laktat 
dioksidasi, mengembalikan $\mathrm{pH}$ darah ke tingkat di mana memungkinkan dilaksankannya glukoneogenesis.

\section{B. METODE PENELITIAN}

Penelitian ini dilakukan di Stadion Universitas Negeri Medan pada April 2017, dengan metode eksperimen. Sampel penelitian berjumlah 10 orang Mahasiswa IKOR angkatan 2014 UNIMED. Metode yang dianggap sesuai dengan permasalahan yang hendak diteliti yaitu menggunakan metode eksperimen.

Rancangan yang akan dilakukan penelitian ini adalah sampel akan dibagi menjadi dua kelompok menjadi kelompok A dan B dengan cara matching by fair. Pengambilan data kadar asam laktat keseluruhan sampel. Kelompok A dan B akan melakukan lari 100 meter setelah itu kelompok A dan B di ukur kadar asam laktat, setelah selesai pada pengukuran maka kelompok A melakukan pemulihan aktif, dengan jogging selama 10 menit. Lalu pada kelompok B setelah lari sprint 100 meter akan melakukan pemulihan aktif dengan duduk/dengan waktu 10 menit. Setelah kelompok A dan B selesai melakukan perlakuan pemulihan maka akan dilakukan test akhir dengan mengukur kembali kadar asam laktat nya.

Pengujian hipotesis digunakan teknik analisa uji-t berpasangan dan uji-t tidak berpasangan (uji $\mathrm{t}$ independent samplet-test) menggunakan SPSS dengan taraf signifikan $\mathrm{p}=0,05$.

\section{HASIL PENELITIAN DAN PEMBAHASAN}

\section{HASIL PENELITIAN}

Berdasarkan hasil penelitian yang dilakukan, maka dilihat rata-rata kadar asam laktat sebelum dan sesudah dilakukan pemulihan aktif (jogging) dan pemulihan pasif (duduk) dengan hasil sebagai berikut :

Tabel 1

Data Deskriptif Kadar Asam Laktat Berdasarkan Sebelum dan Setelah Pemulihan Aktif (Joging) dan Pemulihan Pasif (duduk) Pada Lari Sprint 100 Meter

\begin{tabular}{cccccc}
\hline No & $\begin{array}{c}\text { Kelompok } \\
\text { Pemulihan }\end{array}$ & $\begin{array}{c}\text { Rata- } \\
\text { rata }\end{array}$ & $\begin{array}{c}\text { Standar } \\
\text { Deviasi }\end{array}$ & $\begin{array}{c}\text { Rata- } \\
\text { rata }\end{array}$ & $\begin{array}{c}\text { Standar } \\
\text { Deviasi }\end{array}$ \\
\hline 1 & Aktif (Joging) & 13,96 & 1,46 & 10,68 & 1,42 \\
\hline 2 & Pasif (Duduk) & 13,56 & 1,43 & 12,8 & 0,97 \\
\hline
\end{tabular}


-..-. - Hajil uji persyarat

Hasil uji persyaratan analisis menunjukkan bahwa semua data berasal dari sampel berdistribusi normal dan data dari semua kelompok mempunyai varians populasi yang homogen. Dengan demikian pengujian hipotesis statistik dengan menggunakan uji $\mathrm{t}$ dapat dilakukan. Rangkuman hasil perhitungan hasil analisis data kadar asam laktat pemulihan aktif dan pemulihan pasif dengan uji t pada taraf signifikansi 5\% dapat dilihat pada tabel 4.6.

Tabel 2

Uji T (Paired Samples Test) Data Kadar Asam Laktat Sebelum Dan Sesudah Melakukan Lari Sprint 100 Meter Kelompok Aktif Dan Pasif.

\begin{tabular}{|c|c|c|c|c|}
\hline \multicolumn{2}{|c|}{ Kelompok Pemulihan } & Rerata \pm SD & Nilai $p$ & Keterangan \\
\hline \multirow{2}{*}{$\begin{array}{l}\text { Aktif } \\
\text { (Joging) }\end{array}$} & Pre test & $13,96 \pm 1,46$ & \multirow{2}{*}{0,001} & \multirow{2}{*}{ Signifikan } \\
\hline & Post test & $10,28 \pm 1,40$ & & \\
\hline \multirow{2}{*}{$\begin{array}{l}\text { Pasif } \\
\text { (Duduk) }\end{array}$} & Pre test & $13,56 \pm 1,43$ & \multirow{2}{*}{0,063} & \multirow{2}{*}{ Tidak Signifikan } \\
\hline & Post test & $12,80 \pm 0,97$ & & \\
\hline
\end{tabular}

Dari tabel 2 adalah hasil uji-t berpasangan antara data pre-test dan post test kadar asam laktat pada kelompok pemulihan aktif (joging) dan kelompok pemulihan pasif (duduk). Dapat dilihat pada kelompok pemulihan aktif (jogging) diperoleh nilai significancy $0,001(\mathrm{P}<0,05)$ yang berarti ada perbedaan yang signifikan kadar asam laktat antara pre-test dan post-test. Hal ini berarti ada pengaruh yang signifikan pemulihan aktif terhadap asam laktat setelah melakukanlari sprint 100 meter. Sedangkan dari kelompok pemulihan pasif (duduk) dapat dilihat nilai significancy 0,063 $(\mathrm{P}>0,05)$ yang berarti ada perbedaan yang tidak signifikan. Kadar asam laktat antara pre-test dan post-test. Hal ini berarti tidak terdapat pengaruh yang signifikan pemulihan pasif (duduk) terhadap kadar asam laktat setelah melakukan lari sprint 100 meter.

Tabel 3

Uji T (Independent Samples Test) Data Kadar Asam Laktat Sebelum Dan Sesudah Melakukan Lari Sprint 100 Meter Kelompok Aktif Dan Pasif.

\begin{tabular}{lllll}
\hline Kelompok Pemulihan & Rerata \pm SD & Nilai p & Keterangan \\
\hline Pre test & Aktif (Joging) & $13,96 \pm 1,46$ & \multirow{2}{*}{0,673} & Tidak Signifikan \\
\cline { 2 - 3 } & Pasif (duduk) & $13,56 \pm 1,43$ & &
\end{tabular}

Pada tabel 3 dapat dilihat bahwa dari hasil uji t independen (uji t tidak berpasangan) diperoleh rata-rata kadar asam laktat setelah melakukan lari sprint 100 
meter atau sebelu meakukan pemulihan aktif (jogging) dan pemulihan Pasif (duduk) didapatkan bahwa kadar asam laktat pelari sprint 100 meter pada kelompok Pemulihan aktif diperoleh rata-rata sebesar 13,96 dengan standar deviasi 1,46, sedangkan pada kelompok pasif diperoleh rata-rata sebesar 13,56 dengan standar deviasi 1,43. Hasil uji statistik diperoleh nilai $\mathrm{p}=0,673$. Karena nilai $\mathrm{P}>0,05$ berarti dapat diambil kesimpulan bahwa tidak terdapat perbedaan yang signifikan antara kadar asam laktat pada lari sprint 100 meter mahasiswa IKOR 2014 sebelum diberi pemulihan aktif (jogging) dengan pemberian pemulihan pasif (duduk).

Tabel 4

Uji T (Independent Samples Test) Data Kadar Asam Laktat Sebelum Dan Sesudah Melakukan Lari Sprint 100 Meter Kelompok Aktif Dan Pasif.

\begin{tabular}{lllll}
\hline Kelompok Pemulihan & Rerata \pm SD & Nilai p & Keterangan \\
\hline Post test & Aktif (Joging) & $10,68 \pm 1,42$ & 0,025 \\
\cline { 2 - 5 } & Pasif (duduk) & $12,80 \pm 0,97$ & Signifikan \\
\hline \hline & &
\end{tabular}
berpasangan) diperoleh rata-rata penurunan kadar asam laktat setelah pemulihan aktif (jogging) dan pemulihan pasif (duduk) didapatkan bahwa kadar asam laktat pelari sprint 100 meter pada kelompok pemulihan aktif diperoleh rata-rata sebesar 10,68 dengan standar deviasi 1,42, sedangkan pada kelompok pasif diperoleh rata-rata sebesar 12,80 dengan standar deviasi 0,97. Hasil uji statistik diperoleh nilai $\mathrm{p}=0,025$.

Karena nilai $\mathrm{P}<0,05$ berarti dapat diambil kesimpulan bahwa terdapat perbedaan yang signifikan antara penurunan kadar asam laktat pada lari sprint 100 meter mahasiswa IKOR 2014 yang diberi pemulihan aktif (joging) dibandingkan dengan pemberian pemulihan pasif.

Hal ini berarti terdapat perbedaan yang signifikan pengaruh pemulihan aktif (joging) dengan pemulihan pasif (duduk) terhadap penurunan kadar asam laktat pada lari sprint 100 meter mahasiswa Ilmu Keolahragaan 2014 Universitas Negeri Medan.

\section{PEMBAHASAN PENELITIAN}

a. Pengaruh Pemulihan Aktif Terhadap Penurunan Kadar Asam Laktat Setelah Melakukan Lari Sprint 100 Meter.

Hasil pengukuran kadar asam laktat pada penelitian ini menunjukkan sebelum melakukan pemulihan aktif rerata adalah $13,96 \mathrm{mmol} / \mathrm{L}$ dengan standar deviasi 1,46dan 
setelah melakukan pemulihan aktif (jogging) sebesar $10,68 \mathrm{mmol} / \mathrm{L}$ dengan standar deviasi 1,42. Hasil uji t berpasangan pada kelompok pemulihan aktif (jogging) diperoleh nilai significancy $0,001(\mathrm{P}<0,05)$ yang berarti ada perbedaan yang signifikan penurunan kadar asam laktat antara pre-test dan post-test.

Penurunan kadar asam laktat ini sejalan dengan penelitian-penelitian yang dilakukan oleh banyak peneliti lain diantaranya penelitian yang dilakukan oleh (Afriwardi,2008) dimana pada penelitiannya didapati penurunan kadar kadar asam laktat setelah melakukan lari sprint 100 meter.

Hasil penelitian menunjukkan terjadinya penurunan kadar laktat darah pada pemulihan aktif. Hasil ini sesuai dengan teori dasar yang mengatakan bahwa aktivitas sederhana membantu sirkulasi darah, dalam hal ini mempercepat perpindahan asam laktat dari otot ke hati untuk selanjutnya diubah menjadi glukosa melalui siklus cori. Pemulihan dengan intensitas rendah secara signifikan mengurangi akumulasi asam laktatdan meningkatkan pemulihan otot.

Pemulihan aktif adalah suatu metode pemulihan yang mengacu pada kecepatan menghilangkan kadar asam laktat. Aktivitas yang dilakukan sepertidengan jogging ringan akan menurunkan akumulasi asam laktat. Peningkatan penurunan kadar laktat darah dapat terjadi karena pemulihan aktif setelah olahraga meningkatkan transpor laktat ke hati untuk selanjutnya dijadikan glukosa kembali, yang membuat unsur ini tersedia lagi lewat sirkulasi untuk oksidasi di jaringan, termasuk otot.

Pemulihan aktif meningkatkan aktivitas Ca2+ ATPase disebabkan karena terjadi peningkatan ambilan $\mathrm{Ca} 2+$ yang signifikan yang selanjutnya membebaskan inhibisi yang sebelumnya telah ada sehingga enzim yang inaktif menjadi aktif. Peningkatan ambilan $\mathrm{Ca} 2+$ memiliki beberapa konsekuensi, salah satunya adalah, peningkatan ambilan $\mathrm{Ca} 2+$ dapat memulihkan gangguan yang ditimbulkan selama latihan dan meningkatkan pemulihan otot.

b. Pengaruh Pemulihan Pasif Terhadap Penurunan Kadar Asam Laktat Setelah Melakukan Lari Sprint 100 Meter.

Hasil pengukuran kadar asam laktat pada penelitian ini menunjukkan sebelum melakukan pemulihan pasif rerata adalah $13.56 \mathrm{mmol} / \mathrm{L}$ dengan standar deviasi 1.43 dan setelah melakukan pemulihan pasif (duduk) sebesar 12.8mmol/L dengan standar deviasi 0.97. Hasil uji t berpasangan pada kelompok pemulihan aktif (jogging) diperoleh nilai 
significancy 0,063 ( $\mathrm{P}>0,05)$ yang berarti tidak ada perbedaan yang signifikan penurunan kadar asam laktat antara pre-test dan post-test.

Pemulihan pasif yaitu bentuk istirahat yang berarti hanya berdiam diri tanpa adanya aktifitas fisik apapun, seperti diam, istirahat total (duduk). Pengaruh pemulihan pasif terhadap otot adalah agar otot dapat pulih kembali seperti semula. Prinsip pemulihan pasif ini adalah hampir sama dengan pemulihan aktif, yaitu mengembalikan lagi kondisi fisik seseorang agar seperti semula dan menghilangkan kadar asam laktat.

c. Pemulihan Aktif Lebih Baik Dibandingkan Dengan Pemulihan Pasif Terhadap Penurunan Kadar Asam Laktat Setelah Melakukan Lari Sprint 100 Meter.

Penelitian ini terdiri 2 kelompok dimana kelompok 1 adalah kelompok pemulihan aktif (jogging) sedangkan kelompok 2 adalah kelompok pemulihan pasif (duduk). Masing-masing kelompok berjumlah 5 orang|dengan demikian keseluruhan sampel dalam penelitian ini berjumlah 10 orang.Penelitian ini dilakukan untuk mengetahui perbedaan kadar asam laktat pada pemberian pemulihan aktif dan pemulihan pasif setelah melakukan lari sprint 100 meter. Dari data kelompok aktif (joging) terdapat penurunan kadar asam laktat pada lari sprint 100 meter dengan ratarata sebelum pemulihan aktif (jogging) sebesar 13,96 mmol/L dengan standar deviasi 1,46 dan setelah pemulihan aktif (joging) sebesar 10,68 mmol/L dengan standar deviasi 1,42. Hasil uji t berpasangan pada kelompok pemulihan aktif (jogging) diperoleh nilai significancy $0,001(\mathrm{P}<0,05)$ yang berarti ada perbedaan yang signifikan kadar asam laktat antara pre-test dan post-test.

Berdasarkan data pada kelompok pemulihan pasif (duduk) juga terdapat penurunan kadar asam laktat pada lari sprint 100 meter dengan rata-rata sebelum pemulihan pasif sebesar 13,56 mmol/L dengan standar deviasi 1,43 dan setelah pemulihan pasif selama 10 menit sebesar 12,8 mmol/L dengan standar deviasi 097. Hasil uji t berpasangan pada kelompok pemulihan pasif diperoleh nilai significancy 0,063 $(\mathrm{P}>0,05)$ yang berarti ada perbedaan yang tidak signifikan kadar asam laktat antara pre-test dan post-test pada kelompok pemulihan pasif (duduk). Hal ini berarti tidak terdapat pengaruh yang signifikan pemulihan pasif (duduk) terhadap penurunan kadar asam laktat pada lari sprint 100 meter. Dari hasil tersebut perlu penjelasan yang lebih lanjut untuk mengetahui penyebab terjadinya perbedaan antara perlakuan pemulihan aktif (jogging) dan pemulihan pasif (duduk). 
Asam laktat merupakan produk hasil metabolisme karbohidrat tanpa menggunakan oksigen (metabolisme anaerob). Asam laktat diproduksi di sel otot saat suplai oksigen tidak mencukupi untuk menunjang produksi energi. Penumpukan asam laktat terjadi setelah melakukan aktifitas fisikdan penumpukan asam laktat yang terjadi akan menghambat glikolisis, sehingga timbul kelelahan otot.Melalui proses pembentukan asam laktat dari $1 \mathrm{~mol}$ (180 gram) glikogen otot dihasil 3 molekul ATP. Kadar asam laktat yang lebih dari $6 \mathrm{mmol} / \mathrm{L}$ sudah cukup tinggi untuk berkontribusi terhadap terjadinya kelelahan.

Olahraga yang dilakukan dengan intensitas submaksimal atau intensitas tinggi akan mengakibatkan penumpukan kadar asam laktat semakin besar dan akan mengalami kelelahan. Kadar asam laktat yang melebihi $6 \mathrm{mMol} / \mathrm{L}$ dapat mengganggu mekanisme kerja sel otot sampai pada tingkat koordinasi gerakan. Jogging merupakan cara pemulihan yang cepat meningkatkan konsumsi Oksigen $\left(\mathrm{O}_{2}\right)$ dalam tubuh sehingga dapat mempercepat penurunan kadar asam laktat dalam darah.

\section{KESIMPULAN}

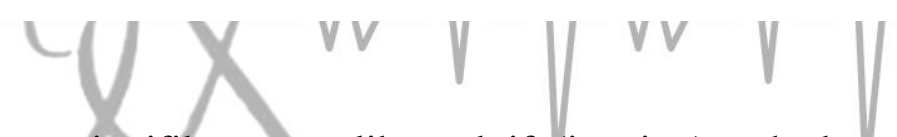

1. Ada pengaruh yang signifikan pemulihan aktif (jogging) terhadap penurunan jumlah kadar asam laktat darah setelah melakukan lari sprint 100 meter dengan nilai significancy $0,001(\mathrm{P}<0,05)$.

2. Ada pengaruh yang tidak signifikan pemulihan pasif (duduk) terhadap penurunan jumlah kadar asam laktat darah setelah melakukan lari sprint 100 meter dengan nilai significancy $0,063(\mathrm{P}>0,05)$.

3. Perlakuan pemulihan aktif (jogging) selama 10 menit lebih baik dalam penurunan jumlah kadar asam laktat darah dibandingkan dengan perlakuan pemulihan pasif (duduk) selama 10 menit terhadap jumlah kadar asam laktat darah setelah melakukan lari sprint 100 meter dengan nilai significancy 0,025

\section{Daftar Pustaka}

Afriwardi, Wenny Rahmalia Rezki (2008). Pengaruh pemulihan aktif dan pemulihan pasif terhadap lamanya perubahan kadar laktat darah pada mahasiswa fakultas kedokteran Universitas Andalas, Padang: Univ. Andalas

Arief. (2011), Pengaruh recovery aktif dan recovery pasif terhadap penurunan kadar CK (enzyme creatine kinase) pada Cabang Atletik Nomor Lari Jarak Jauh. DKI Jakarta. 
Bompa T, O, (1994). Teori and Metodology of Training: Kendall Hunt Publising Company.

Danardono hajar, (2013). Perbedaan Pengaruh Recovery Aktif, Corstability, Dan Pasif, Sesudah Latihan Maksimum Terhadap Penurunan Kadar Asam Laktat Ditinjau Dari Indeks Massa Tubuh

Destiana Ayu Ningrum (2012). Perbandingan metodehydrotherapy massage dan massage manual terhadap pemulihan kelelahan pasca olahraga anaerobik lactacid

Djumijar (2007) Atletik dan Lari Sprint. Banjarnegara

Falks. (1995). Blood Lactate Concentration Following Exercise. International jurnal sport medicine

Fox, El, Bowers, R.W. And Foss, M.L. (1998). The Fisiological Basis Of Physical Education And Athletics $\left(4^{\text {th }}\right.$ Ed). Philadelpia: Saunder Collage

Harsono, (1998). Coaching Dan Aspek-Aspek Psikologis Dalam Coaching, Jakarta; C.V Tambak Kusuma.

Irwanyah. (2006), Pendidikan Jasmani Olahraga Dan Kesehatan. Jakarta PT Grafindo Media Pratama

Jansen (2012). Latihan Laktat Denyut Nadi. Jakarta : Grafiti

Josef Nossek (1982). Teori Umum Latihan. Institute Nasional Olahraga Lagos Pan African Press LTD. Lagos

Purnomo E. (2007), Dasar-dasar Gerak Atletik: Alfemedia ,Jakarta.

Prayogi Guntara (2014) Rengaruh Recovery Aktif Dengan Recovery Pasif Terhadap Penurunan Kadar Asam Laktat. Bandung: UPI

Sugiyono (2015). Metode Penelitian Pendidikan, Bandung.

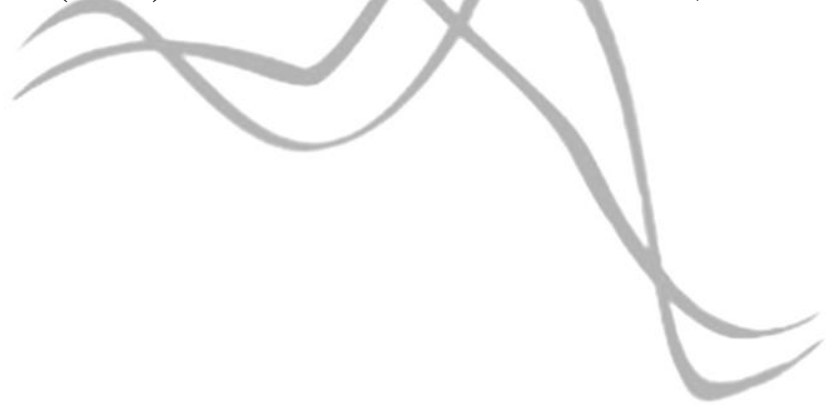

